\title{
Üniversite Gençliğinin Meslek Seçimi ve Gelecek Beklentileri: Akdeniz Üniversitesi Edebiyat Fakültesi Örneği
}

\author{
DOI: 10.26466/opus.393634 \\ * \\ Fatih Tezcan $^{*}$ \\ * Akdeniz Üniversitesi, Sosyal Bilimler Enstitüsü, Antalya / Türkiye. \\ E-Posta: fatih tezcan90@hotmail.com \\ ORCID: 0000-0001-8184-5037
}

Öz

Akdeniz Üniversitesi Edebiyat Fakültesi'nde yapılan bu çalışma, öğrencilerin meslek seçimi, bölüm tercihi ve gelecek beklentisi üzerinedir. Edebiyat Fakültesi bünyesinde bulunan her bölümden (Alman Dili ve Edebiyatı, İngiliz Dili ve Edebiyatı, Arkeoloji, Felsefe, Coğrafya, Psikoloji, Sanat Tarihi, Sosyoloji, Tarih, Gerontoloji, Türk Dili ve Edebiyatl, Eskiçă̆ Dilleri ve Kültürleri) toplamda 35 öğrencinin katılımıyla gerçekleştirilen bu çalışmada yarı-yapılandırılmış soru formu ve görüşme tekniği kullanılmıştır. Aynı zamanda Edebiyat Fakültesi öğrencilerinin yaşam memnuniyetlerine, boş zaman etkinliklerine, hayallerine, kaygılarına, ikili ilişkilerin onlar için ne ifade ettiğine, kendi kuşakları hakkındaki görüşlerine, kuşaklararası diyaloglarına yer verilmiş ve öğrencileri hayata nelerin bağladığı, nelere tutundukları da irdelenmeye çalışılmıştır. Bu bağlamda farklı bölümden öğrencilerin gelecek beklentileri, kaygıları vb. konularının ne ölçüde değisstiği sosyo-ekonomik faktörler göz önünde bulundurularak incelenmesi amaçlanmıştır. Sonuçta Akdeniz Üniversitesi Edebiyat Fakültesi öğrencilerinin yaşamlarından bir kesit sunularak betimleyici bir çalışmanın ortaya konması hedeflenmiştir.

Anahtar Kelimeler: Gelecek beklentisi, Kuşaklararası diyalog, Meslek seçimi, Üniversite gençliği, Yaşam memnuniyeti. 


\title{
Career Choice and Future Expectations of University Youth: Case of Faculty of Letters of Akdeniz University
}

\begin{abstract}
This study, conducted at the Faculty of Letters of Akdeniz University, is about students' career choice, department preference and future expectation. Semi-structured questionnaire and interview technique were used in this study, which was conducted with the participation of 35 students at total in each department (German Language and Literature, English Language and Literature, Archaeology, Philosophy, Geography, Psychology, History of Art, Sociology, History, Gerontology, Turkish Language and Literature, Ancient Languages and Cultures) in the Faculty of Letters. At the same time the students' life satisfaction, leisure activities, dreams, concerns, close relationships, opinions about generations and intergenerational dialogue have been involved in this study. Also in this study, it has been tried to understand how the students are connected to life and how they cope with the challenges. Within this context, considering the socio-economic factors, it has been aimed to examine the future expectations and concerns of the students from different departments. As a result, by representing a descriptive study, it has been tried to show a chapter of the lives of the students of the Faculty of Letters of Akdeniz University.
\end{abstract}

Keywords: Career choice, Future expectation, Intergenerational dialogue, Life satisfaction, University youth.

OPUS (c) Uluslararası Toplum Araştırmaları Dergisi-International Journal of Society Researches ISSN:2528-9527 E-ISSN : 2528-9535

http://opusjournal.net 


\section{Giriş}

Gençlik, tanımlanması zor olan kavramlardan biridir. Fiziksel, biyolojik bir gençlik tanımı yapılması kolay görünse de, sosyal bir kategori olarak ele alındığında, sınırları belirsizleşir. Her ne kadar genç kavramı her zaman var olmuş olsa da (örneğin insanlar kendilerini hep başkalarına göre daha genç veya yaşlı olarak tanımlasalar da), bir sosyal kategori olarak gençlik, modernitenin bir ürünüdür (Lüküslü, 2015, s. 22). Bu yüzden, ister yaş sınıflandırmalarıyla olsun, ister kuşaklara göre olsun, sınırlar tamamıla değişkendir ve manipülasyonların temel meselesidir. Bourdieu'ya göre: "sosyologun mesleki refleksi, yaşlar arası bölünmelerin keyfi olduğunu hatırlatmaktır. Bu, zenginliğin nerede başladığının bilinememesi gibi yaşlılığın da hangi yaştan itibaren başladığının bilinemeyeceğini söyleyen Pareto paradoksudur. Aslında, gençlik ile yaşlılık arasındaki sınır, tüm toplumlarda bir mücadele meselesidir" (Bourdieu, 1981/2016, s. 173). Genel bir ifade ile gençlik, çocukluktan yetişkinliğe geçişteki süreç olarak tanımlanır. Ancak Bourdieu'ya göre (1981/2016, s. 174) yaşlara, sınıflara ve cinsiyetlere göre yapılan bir sınıflandırma, her zaman sınırlar dayatmayı ve herkesin bağlı kalması gereken bir düzeni ve herkesin kendi yerinde kalması gereken bir düzeni tesis etmeyi ifade eder. Her tanımlamanın bir sınırlama yapma, öteki üzerinden hareketle özellikler belirleme şeklinde ilerlediği göz önünde bulundurulsa da gençlik, buna rağmen, "oluş" gereği çocukluk, yetişkinlik veya yaşlılığa kıyasla daha bir "geçici"dir. Gençlik, çocukluk, yetişkinlik ve yaşlılık gibi görece daha uzun, daha "oturaklı" bir süreç değildir. Çünkü çocukluk bir başlangıcı, yetişkinlik erişilmesi gereken bir konumu, yaşlılık da kaçınılmaz sonun kabul edilişini ifade eder. Gençlik ise yalnızca bir geçişi, bitirilmesi, tamamlanması beklenen bir süreci, var olmaktan ziyade bir "oluşu" simgeler. Çocukluk hoş görülen, sevilen bir dönem, yetişkinlik saygı duyulan/kazanılan bir konum, yaşlılık ise hürmet edilen onaylanmış bir son iken gençlik "korkulan" "belirsiz" "tehdit oluşturan" bir süreç ya da en iyi ihtimalle bir potansiyel, işlenmesi, şekil verilmesi gereken bir kaynak, başkalarının elindeki bir araç/alettir. 
Günümüz Batı toplumlarında "gençlik" kavramı ile açıklanan yaşam döneminin uzadığı sosyal bilimciler tarafından öne sürülmektedir. Günümüzde, bu yaş aralığının gün geçtikçe genişlediği, "gençlik dönemi" algısının 12 yaşa kadar indiği ve 30'lu yaşların ortasına kadar devam ettiği söylenebilir. Bu durum gençlik kavramının tanımlanmasında yaşanan zorluğu açılamanın yanında, sosyal bir kategori olarak gençlik üzerine olan ilginin de son yıllarda giderek artmasını sağlamıştır. Gençliğe ilişkin artan bu ilginin bir yansıması olarak, uzayan bu dönemin eğitim ile olan ilişkisi de göz önüne alındığında bireylerin yaşamlarını, geleceklerini belirlemede öne çıan meslek seçiminin araştırılması da kaçınılmaz olmaktadır. Bu çalışmanın örneklemini oluşturan Akdeniz Üniversitesi Edebiyat Fakültesi öğrencileri ile yapılan görüşmelere geçmeden önce gençlik üzerine ortaya konan teorik yaklaşımları ele almak yararlı olacaktır.

\section{Gençliğe Yönelik Farklı Teorik Yaklaşımlar}

Gençlik hakkındaki politik ve sosyolojik tartışmalarda, gençliğin bir yaş aralığ $\mathrm{m} 1$ veya insan yaşamında ana evre olarak görülen yetişkinliğe geçişteki bir süreç/basamak mı, yoksa yaşam içinde kendi karakteristiklerine sahip olan bir dönem mi olduğuna dair sorular öne çıkmaktadır (Bendit, 2006, s. 54). Yaş aralığı ve yetişkinliğge geçiş olarak ele alındığında gençlik aşılmasi/geçilmesi/üstesinden gelinmesi gereken bir süreç olarak karş1mıza çıkmaktadır. Yetişkinliğin gerçekleşmesi için de bir işe sahip olmanın, evden ayrılmanın ve evlenmenin yerine getirilmiş olması gerekir. Böylelikle birey bağımsızlığını kazanmış olur. Bu klasik görüşlerin yayında sosyal bir kategori olarak da gençlik ele alınabilir. Böylece kendi karakteristiklerine sahip olan gençlik, insan yaşamının farklı bir dönemi olarak önem kazanır.

\section{Bir Yaş Aralığı Olarak Gençlik}

Genellikle politik alanda gençliğin tanımlanması belirli bir yaş aralığı ile yapılmaktadır. Neredeyse bütün politik programlarda gençlerin topluma "uyum sağlamaları" amaçlanmıştır. Günümüz Batı toplumlarında "gençlik" kavramı ile açıklanan yaşam döneminin uzadığı sosyal bilimciler ta- 
rafından öne sürülmektedir. Avrupa ülkelerinde 15-25 ve bazı durumlarda da 14-30 yaş arası gruplar genç olarak tanımlanmaktadır. Yaş aralığının çizilmesindeki rol oynayan etkenler arasında eğitim ve istihdam gelmektedir (Bendit, 2006, s. 55). Her iki etkenin de yıllar içinde uzaması, bireyin bağımlı nüfusta kalmasını beraberinde getirmiştir. Bu yüzden de yapılan yaş aralığı tanımlamalarının değişime uğradığı görülmektedir. Bu durum bir ölçüde genelleme yapmayı anlamsız kılmaktadır. Çünkü eğitimin ve istihdamın gençlik üzerindeki şekillendirici rolü göz önüne alınırsa, her gencin eğitim süresinin farklılaştığı, işe girme yaşının da değiştiği düşünülürse, gençlik oldukça kişisel bir konu haline gelmektedir. Ayrıca gençler arasında eğitim gördüğü süre içinde de çalışma yaygındır. Ancak bu noktada yaş aralığının uzamasının başka bir nedeni de istihdamın değişen yapısıdır. Sosyal refah politikalarının aksine günümüz neoliberal politikaların bir sonucu olarak iş yaşamında ortaya çıkan esneklik her şekilde bireyin geleceğini belirsizleştirmekte, bağımsızlığa kavuşmasında bir engel oluşturmaktadır.

Sosyologlar yetişkin yaşamına girişi şu üç unsura bağlamaktadır: aileden ayrılma, çalışma yaşamına atılma ve evlenme. Üç unsur gerçekleştiğinde genç birey artık yetişkinliğe adım atmıştır. Yetişkinliğe geçişin uzaması sonucu bitmeyen gençlik dönemini "genç-yetişkin" veya "ergen-yetişkin" (adulescent) kavramları karşılamaktadır. 25-35 yaş arası gençlik kesimine karşılık gelen bu kavram Fransızca ergen (adolescent) ile yetişkin (adulte) kelimelerinin bir araya getirilmesiyle oluşturulmuştur (akt. Firat, 2013, s. 26-49).

Genç bireylerin bağımlı nüfus içinde kalmaları dolayısıyla gençliğin tek başına ele alınamayacağı iddia edilmiştir (Wyn, 2011). Uzayan yaş ile birlikte gençlerin ailelerinden ayrılmamaları, gençliğin aile ile birlikte değerlendirilmesinin, gençlik ve aile sosyolojisinin bir arada kullanılmasının yararlı olacağı düşünülmüştür. 1950'lerden 1970'lerin başına dek genelde gençler okulu 15 yaşında terk eder ve yirmilerinin başında da evden ayr1lırlardı. Elbette bu örüntü değişime uğramış ve "gençlik süreci" rahatça tanımlanmayan bir hal almaya başlamıştır. Artık gençlerin yaşanan değişimin sonucunda aileleri ile daha çok vakit geçirdikleri ortaya çıkmıştır. Bundan dolayı da ailelerin, gençler üzerindeki etkisi artmaktadır. Örneğin 2006 'da 20 ile 34 yaşları arasındaki Avustralyalı gençlerin \%23'ünün aileleri ile birlikte kaldıkları belirlenmiştir. Halbuki bu oran 1986 da yaklaşık 
olarak \%19'du (Wyn, 2011, s. 36). Ayrıca gençlerin, ailelerinin yanından ayrılıp, farklı eve çıktıklarında da bağımlılıklarının devam ettiği, ekonomik ve diğer desteklerden de yararlandıkları düşünülmelidir.

\section{Risklere Maruz Kalabilecek Bir Grup Olarak Gençlik}

$\mathrm{Bu}$ başlık altında gençlik, içinde birçok riski barındıran bir grup olarak incelenmekte ve yeniden, eğitim, istihdam konuları karşımıza çıkmaktadır. Gençlerin sahip oldukları riskler arasında başarısız bir eğitimden geçmeleri, iş bulamamaları ve evsiz kalmaları yer almaktadır. Taşıdıkları riskler, onların sorunlu bir grup olarak görülmelerine neden olmaktadır. Ayrıca alkol ve madde bağımlılığı, akli denge sorunları ve artan cinsel eğilimler de risk olarak görülmektedir (Bendit, 2006, s. 56). Gençliğin sorunlu bir grup olarak tanımlanması, "bir tehdit olarak gençlik" (Lüküslü ve Yücel, 2013, s. 12) görüşü ile uyum içindedir. Elbette bu tarz bir tanımlama, vakalar üzerinden genelleme ile yapılmaktadır. Ancak gençlerin "tehdit" içerdiği düşüncesinin toplumda var olduğu gerçeğini de değiştirmez. Bu risklerin yalnızca gençlere özgü olduğu yanılsamasının oluşmaması için doğrudan gençler ile ilişki kurmak yerine uygulanan ekonomi politikaları gibi yapısal sorunlar öne çıkarılabilir. Yoksulluk, evsizlik, işsizlik, eğitimsizlik toplumda herhangi bir gruba özgü değildir. Ancak alkol ve madde bağımlılığı, artan cinselliğe bağlı suçların ortaya çıkması genelde gençler ile özdeşleştirilmektedir. Özdeşleştirmek başlı başına "sorunlu" bir davranıştır. Yoksa gençliğin kendisi sorunlu ya da riskli değildir. Gençlerin risk unsuru taşıyan davranışları, içinde bulundukları sürecin belirsizliğinin bir sonucu olarak görülebilir.

Gençlerin sorunlu bir grup olarak değerlendirilmesi, alt-kültürler ile de ilişkilendirilebilir. Gençlerin sahip oldukları alt-kültürler onların sapkın olarak suçlanmasına neden olsa da aslında alt-kültürleri ile gençler, kültürel alanda küreselleşmenin etkisine karşın özgünlüklerini ortaya koymaya çalışmaktadırlar. Gençlik alt-kültürlerinin sosyolojisinde sosyal sınıf ve günlük yaşam deneyimleri arasındaki ilişki incelenmektedir ve teorik çerçevesinde Pierre Bourdieu'nun etkisi vardır. Ebeveynlerin mevcut sınıfları ve eğitim düzeyleri temel faktörler arasındadır. Sosyal sınıf, iş̧̧̧i sınıfı çocuklarının birlikteliğine ya da orta sınıfın çocuklarının birlikteliğine işaret eden bir sosyal grup değildir. Sosyal sınıf bir yapıdır, bireyin 
yaşamında doğrudan etkili olur. Ailelerinin mevcut durumunun etkisinin yanında Habitus kavramı önem kazanmaktadır. Gençlerin sahip oldukları habitus (yaşam alanı) ailelerininkinden farklılık göstermektedir. Aynı zamanda alt-kültürler de homojenlik göstermemektedir (O'Connor, 2004, s. 409-410).

\section{Bir Geçiş Aşaması Olarak Gençlik}

$\mathrm{Bu}$ başlık altında gençlik, ulaşılması/erişilmesi gereken yetişkinlik konumunun önündeki bir aşama olarak ele alınır. Bireysel gelişimde ve toplumsallaşma süreci içinde gencin topluma tamamen uyum sağlaması verili kültürel normları öğrenmesi ile olanaklıdır. Ancak modern ve postmodern endüstri toplumlarında yetişkinliğe geçiş uzamakta ve süreç karmaşıklaşmaktadır. Çünkü eğitim süreci uzamakta ve lisansüstü programlar yaygınlaşmakta, sosyal yaşam değişmekte ve bireyselleşmektedir. Aslında bu yüzden yetişkinliğe giden yollar da çeşitlenmektedir. Günümüzde bireyler yetişkinlik konumlarını, toplum tarafından belirlenmiş yolları takip etmenin yerine, müzakere süreci ile belirlemektedirler. Eskisi gibi önce eğitim sonra iş çizgisi kırılmakta, eğitim+iş şeklinde, önceliklerinin önemi kalmadan, yetişkinlik süreci ilerlemektedir (Bendit, 2006, s. 5758).

Yetişkinliğe geçişin uzaması konusunda karşımıza yeniden, iş piyasasının esnekleşmiş, güvencesizleşmiş olması çıkmaktadır. Genç bireylerin konut ve aile konusunda bağımlılıkları artmaktadır. Gençlerin işsiz kalmalarına yönelik olarak beş özellik (O'Reilly vd., 2015) öne çıkarılmaktadır: esneklik, eğitim, göç, aile mirası ve Avrupa Birliği politikaları. Neoliberal politikaların sosyal refah politikalarının aksine güvence ve tam istihdam sağlayamıyor oluşu post-fordist dönemin ayrıcı niteliğidir. Fordist üretim ilişkilerinde işe başladığ fabrikadan emekli olabilen bireylerin aksine üretim biçiminde esnekliğin gelmesi ile üretim ilişkilerinde yaşanan dönüşüm sonrası istihdam güvencesinin kaybı yaşanmış, sürekli değişen işler, taşeronlaşma, "eğreti istihdam" (Temiz, 2004) kavramını doğurmuştur. Bireyler, yaşamlarının ve geleceklerinin belirsizliği ile Sennett'in de Karakter Aşınması'nda (1998/2011) öne sürdügü gibi değişen iş piyasasının getirdiği ahlak ile önceki nesilden edinilen ahlak arasında yaşanan ikilemin de etkisi ile bir anlatı oluşturamamaktadırlar. Günümüzde uzayan 
eğitimin yanına da böylece lisansüstü eğitimler, doktora programları eklenerek isteyerek ya da istemeyerek yetişkinliğe yetişilememekte, ge(n)ç kalınmaktadır.

Bireylerin yetişkinliğe geçişi başarı ile atlatmaları büyük ölçüde kültürel sermayeleri (aile tarafindan desteklenmek, bölgesel ve toplumsal cinsiyet dolayısıyla oluşan fırsatlar ile kısıtlamalar) ile ilişkilendirilmektedir. Bireyler kendi paralarını kazanmadıkça, ayrı bir eve çıkmadıkça tamamen yetişkinliğe erişemedikleri kabul edildiği için karşımıza geç-ergenlik (post-ergenlik) ve genç-yetişkinlik kavramları çıkmaktadır.

\section{Kendine Özgü Karakteristiklere Sahip Bir Dönem Olarak Gençlik}

Yaş aralığı ve yetişkinliğe geçiş sürecinin karşısında oluşan bu başlıkta, geç-ergenlik ve genç-yetişkinlik kavramları öncülüğünde, ekonomik ve teknolojik gelişmelerin, uzun süreli eğitimin ve artan mesleki uzmanlık niteliklerin gençlik üzerindeki etkisi sonucu yaşamın yeni bir evresi olarak "gençlik" oluşmaktadır. Gençlik yaşamı, yaşam döngüsü içinde kendine özgü uzun bir döneme girmiş olur. Böylece gençlik evresi ya da kavramın işlevsel eşdeğeri olarak "gençlik yaşamı" post-endüstriyel toplumlarda önemli sosyolojik, pratik ve politik bir kategori haline gelir. Ekonomik ve sosyal modernleşme bağlamında gençlik artık belirleyici bir yaşam evresi olarak düşünülür. Çünkü gençler iş konusunda uzmanlaşmak için gerekli nitelikleri ve yönelimleri elde etmek ve yaşamlarının geri kalanında merkezi etkisi olacak olan kararları almak zorundadırlar. Bu evrede yaşanacak olan başarısızlık, mesleki kariyer ve biyografik yörüngeler için önemli ön koşulların tehlikede olduğu anlamına gelir (Bendit, 2006, s. 63).

Eleştirel bir bakış açısı ile "gençlik yaşamı" teorisi de klasik geçiş sürecindeki gençlik anlayışı içinde değerlendirilmeye uygundur. Çünkü bu evrede gerçekleştirilmesi gereken görevler, gelecekteki "yetişkin” yaşamına hazırlığı ifade eder. Gençlik yaşamı yaklaşımının geleneksel geçiş süreci anlayışının dışına çıktığı nokta ise geç-ergenlik ve genç-yetişkin kavramlarının dahil olduğu gençliğin, yalnızca yaşamı belirleyen önemli niteliklerin edinildiği bir aşama olarak ele almamasıdır. Aynı zamanda gençlik, bireylerin özerk kültürel örüntülerini ve yaşam tarzlarını geliştirdikleri uzun/uzatılmış bir yaşam evresi olarak değerlendirilmektedir. Bu 
yaklaşımda sosyalleşme, mevcut normların ve yaşam örüntülerinin değiştirilmeden aktarımının sağlandığı tek yönlü bir işlem olarak görülmez. Yaşam döngüsünün bu evresinde gençler gelecekteki kişisel ve mesleki yaşamları ile ilgili olan beceri ve yeterlilikleri öğrenmekle kalmazlar. Ayrıca kendi değerlerini, sosyal ve kültürel normlarını ve toplumsal değişimin ana failleri haline gelmelerini sağlayan yetkinlikleri geliştirirler (Bendit, 2006, s. 63).

Buraya kadar gençlik hakkında değinilen görüşlerde benzerlikler ve farklılıklar bulunmaktadır. Yapılan açıklamalar gençliğin farklı yönlerine eğilmektedir. Bu yüzden homojen bir gençlik tanımından öte, gençliklerden söz edilebilir. Öncelikle gençliğin yaş aralığının uzadığı kabul edilmektedir, ancak yaş aralığı belirlemek sınırlarının belirsizleşmesi dolayısıyla çok anlamlı görünmemektedir. Bir şekilde bütün görüşler gençliği bir evre olarak ele almaktadır. Sonuç itibariyle gençlik de çocukluk, yaşl1lık gibi yaşamda bireyin deneyimlediği dönemlerden biridir. Ancak gençliğin yetişkinliğe geçişte adeta bir basamak gibi görülmesi, bu kavramın kendi gerçekliği ve bağlamı içinde değerlendirmeyi zorlaştırmaktadır. Bu noktadan hareketle gençliğe içeriden bir bakış olanağı sunması amaçlanan bu çalışmanın sonraki bölümünde Akdeniz Üniversitesi Edebiyat Fakültesi öğrencileri ile yapılan görüşmelere yer verilecektir.

\section{Yöntem}

Araştırmada öncelikli olarak Edebiyat Fakültesi öğrencilerinin öğretim gördükleri bölümleri nasıl tercih ettiklerinin ve kararlarında etkili olan faktörlerin öğrenilmesi amaçlanmıştır. Çalışmada nitel veri toplama aracı olarak yarı-yapılandırılmış soru formu ve görüşme tekniği kullanılmıştır. Katılımcılara "neden ... bölümünü tercih ettin?" şeklinde soru yöneltildiğinde, öğrencilerin gerildikleri, bir ölçüde sorguya çekildikleri hissine kapıldıkları gözlenmiştir. Bundan dolayı H. S. Becker'in (1998/2014, s. 105108) "neden yerine nasıl" şeklindeki soru sorma pratiğine geçilmiş, Berg ve Lune'un “Görüşmeye Tiyatral Bir Bakış"1 (2014/2015, s. 129-188) örnek alınarak bazı katılımcılarla sohbet havasında geçen, bazen de soru formu kullanılmadan, "laf arasında" yanıtların arandığı konuşmalar yapılmıştır. Ayrıca boş zaman etkinlikleri, hayaller, ikili ilişkiler ve kuşaklararası di- 
yalog konularında öğrencilerin konuşmaya daha fazla istekli ve rahat oldukları gözlenmesine rağmen, demografik sorular konusunda ise isteksiz oldukları görülmüştür. Elbette bu durum her katılımcı için geçerli olmadığı gibi, sorulara verilen yanıtların niteliği de katılımcılara ve okudukları bölüme göre de değişim göstermektedir. Örneğin anket formu ile görüşmeler yaparak ödev hazırlayan Gerontoloji bölümü öğrencileri ((K7, 22, $\mathrm{K}),(\mathrm{K} 8,21, \mathrm{E}))$ kendi çalışmaları ile benzerlik kurarak, verdikleri yanıtlara daha fazla özen göstermişlerdir.

\section{Çalışma Grubu}

Bu çalışma 2016-2017 Eğitim-Öğretim Yılı Bahar Dönemi'nde Akdeniz Üniversitesi Edebiyat Fakültesi bünyesinde bulunan her bölümden (Alman Dili ve Edebiyatı, İngiliz Dili ve Edebiyatı, Arkeoloji, Felsefe, Coğrafya, Psikoloji, Sanat Tarihi, Sosyoloji, Tarih, Gerontoloji, Türk Dili ve Edebiyatı, Eskiçağ Dilleri ve Kültürleri) toplamda 35 öğrencinin katıl1miyla gerçekleştirilmiştir. Öğrencilerin cinsiyeti, yaşı, okuduğu bölümü ve sınıfı, doğum yeri, anne-babalarının mesleki durumları Ek 1- Katılımcıların Listesi başlığı altında verilmiştir.

\section{Araştırma Bulguları}

\section{Meslek Seçimi}

Dört yıllık üniversite eğitiminin tamamlanmasının ardından büyük olasılıkla "hayata atılacağı", seçtiği bölümle ilgili olan bir alanda çalışmaya başlayacağı düşünülen öğrencilerin meslek tercihlerini nasıl yaptıkları araştırılmıştır. Yaşamlarının geri kalanını şekillendirecek olan bu tercih konusunda öğrencilerin verdiği yanıtların bilinçli seçim konusunda çeşitlilik göstermesi beklenirken, meslek seçiminin ciddiye alınması, tercihin bireyin ilgi ve yetenekleri doğrultusunda, yaptığı araştırma sonucunda sevdiği bir alanda çalışma düşüncesinden hareket eden öğrencilerin yanında, rastlantısal olarak, o anın getirdiğ i "boşta kalmayayım" korkusuyla veya bir kişinin, bir "uyarıcının" etkisi ile "bir şekilde üniversiteye gireyim" (K14, 19, K). "öyle ya da böyle bir mesleğim olsun" (K24, 22, E) düşüncesine 
sahip olan öğrencilerin sayısının da azımsanmayacak ölçüde olduğu görülmektedir. Ancak Psikoloji 1. sınıf öğrencilerine göre okudukları bölüm:

"Kendi sorularıma cevap bulmak, kendi yaşamım üzerinden başkalarının hayatlarım daha yaşanabilir kılmak istememden dolayı ilk tercihimdi." (K1, 19, K). "Kişisel özelliklerime yakın buldum ve yapabileceğimi düşündüm." (K4, 25, K).

Aynı zamanda Sosyoloji 3. sınıf öğrencisi için de "başkalarının hayatlarına dokunabilmek" (K17, 21, K) isteği öne çıkmaktadır: "Değişimin bir parçası olmak için tercih ettim." (K17, 21, K). "Lisede okuduğum kitaplarm içerikleri ve onların beni gözleme dayalı bilimsel bir uğraşıya yönlendirmesi. Aslında zaten sosyoloji okuyormuşum lisede de." (K20, 26, K).

Oysaki Sanat Tarihi bölümünde 4. sinıfta okuyan bir öğrenci içinse meslek seçimi daha çok "bütçeyi aşmadan" sınav sonucuna göre gerçekleşmiştir: "Puanımız yettiği ölçüde..." (K9, 25, K).

Ayrıca öğrenciler arasında tercih ettikleri bölüme karşı fazla ilgi duymayanların da olduğu gözlenmiştir: "isteyerek değil, mezun kalmamak için." (K14, 19, K). "Meraktan... Akdeniz'e gelmem ise zorunluluktan. Dicle'de okuyordum, aile [Antalya'ya] gelince yatay geçiş yaptım." (K22, 22, E). "PDR istiyordum, 2-3 yıl hazırlandım. 1 sene daha boşa gitmesin, belki severim diye felsefeye geldim."(K24, 22, E). Aynı zamanda katılımcilar arasında tercih ettikleri bölüme karşı ilginin, sonradan oluştuğunu belirtenler de vardır. İlgilerinin değişiminin ekonomik nedenler ve kişisel başarı dolayısıyla gerçekleştiği görülmüştür: "Lise 1'de Jinekoloji istiyordum, Ege Üniversitesi'nde. Maddi açıdan ailem olmaz dedi. Ben de yapabileceğimi düşündü̈̆̈̈̈m gerontoloji bölümüne ilgi duymaya başladım..." (K7, 22, K). "Başlarda İlahiyat istiyordum ama Tarihin içine girdikçe lisede ilgim arttı ve daha başarılı olacağımı düşündüğüm için seçtim." (K29, 22, E).

İstenilen bir bölüme gir(e)meyen öğrencilerin de memnuniyet düzeylerinin düşük olması şaşırtıcı değildir. Bu durum özellikle Alman Dili ve Edebiyatı bölümünde görülmektedir. Bu bölümün öğrencileri ile yapılan görüşmelerde ilk tercihlerinin İngiliz Dili ve Edebiyatı olduğu ancak puana göre yapılan tercih sıralamasında "mezun kalmamak adına" görece daha düşük puanlı olan Alman Dili ve Edebiyatının da alt sıralardaki yerini aldığını belirten öğrenciler, bu dilin zorluğundan yakınmaktadır. "İngilizce istiyorduk, Almanca geldi ve bu bölümden memnun değilim. Ailem de dile yok dedi ve onların ısrarı ile Çocuk Gelişimi ve Ĕ̆itimi okudum. Ancak ondan 
sonra dil okuyamaya başladım o da Almanca oldu."(K35, 21, K). Benzer örnekler Türk Dili ve Edebiyatı öğrencileri için de geçerlidir: "Aslında PDR hedeflemiştim, puanım yetmedi, dersler de ağır geldi bana ilgi duymayınca çalışasım gelmiyor, geçiş yapmak istiyorum." (K15, 19, K). "ilk tercihim hukuktu, olmadl, tekrar denemeyi düşünüyorum." (K16, 19, K). "Abim sosyoloji mezunu, ben de istiyordum ama olmadl, olmayınca da felsefeyi yazdım." (K23, 22, K).

Bunun yanında tercih edilen bölüme ilginin "dışardan bir uyarıcı" ile geldiği durumlar da söz konusudur: "Tercih döneminde arkadaş kanıma girdi." (K19, 21, K). "Abim önerdi, sonradan ilgimi de çekti, seviyorum bölümü [Sanat Tarihi]." (K10, 22, E). "Lisede müze gezisine gittikten sonra bölüme artan ilgimden dolayı arkeolojiyi seçtim..." (K21, 22, K). "Ablam Gazi Üniversitesi'nde sosyoloji okuyor, arkadaşlarım da [bölümdeki] alan araştırmalarından bahsettiler, cezp etti." (K18, 21, K).

Görüşme yapılan öğrencilerin düşünceleri doğrultusunda, meslek seçiminde genel anlamda üç farklı eğilim ağırlık kazanmaktadır. İlki; bireylerin yaşam öykülerinin seçtikleri bölümde etkili olması ve başka insanlar üzerinde etki sahibi olma, faydalı olma isteği ile ilkeli (özgeci ve idealist) tercih. İkincisi; üniversite sınav sonucuna göre alınan puanın belirleyici olduğu fazla hayalci olmayan ve yarını bugünden düşünmenin bir şeyi değiştirmeyeceği, etkili veya uygun olmayacağı düşünülerek yapılan plansız tercih. Üçüncüsü ise ani gelişen olayların (müze gezisi gibi), bir arkadaşın etkisi ya da yakın çevrenin tercih edilen bölümde okumuş olması ve ebeveynlerin öğrencinin okuyacağı bölüme karar vermesi ile yapılan edilgen tercih. Ailenin isteği ile yapılan tercihlerin öğrenci için her zaman olumlu sonuçlar doğurmadığı açıktır. Örneğin Alman Dili ve Edebiyatını, ailesi tarafından garanti meslek olarak düşünülen Çocuk Gelişimi ve Eğitimi'ni tamamladıktan sonra okumaya başlayan (K35, 21, K) öğrencinin aksine Gerontoloji 2. Sınıf öğrencisi için durum farklılık göstermektedir: "Sınav sonucu sonrası mühendislik gibi düşündüm. Sonra dayım bölümden [Gerontoloji] bahsetti 1-2 kişi ile görüştürdü, geleceği var dedi. Bölümde okuyanlarla konuştukça da yaşlılarla iletişim kurmaya ilgim arttı, seviyorum." (K8, 21, E). Bu öğrencinin tercihi ise hem sinav sonucuna göre hem de bir aile ferdinin etkisi gerçekleşmiştir. Bu durum da aslında bir ölçüde plansız tercihte ailenin görünmez onayının etkisi olduğu söylenebilir. Ayrıca bölüm tercihinin sevilerek yapılması memnuniyet arttırıcı olsa da seçilen mesleğin "geleceğinin ve iş olanaklarının olması" da belirleyicilik 
göstermekte, Gerontoloji bölümünün tercih nedenleri arasında "geleceğin mesleği" $(\mathrm{K} 7,22, \mathrm{~K}),(\mathrm{K} 8,21$, E) olduğu düşüncesi bulunmaktadır.

Gözlenen eğilimlerin iç içe geçtiği durumlar da söz konusudur: "Her ne kadar şimdi bölümün niteliklerinin bana uygunluğunu söyleyebilsem de arkadaşım Ferhat etkili oldu aslında. \%60 Ferhat ve yaşamımda etkili olan dayımın üniversite okumam konusundaki isteği..." (K12, 28, E).

Göz önünde bulundurulması gereken bir diğer nokta da elbette öğrencilerin ekonomik durumlarıdır. Birçok katılımcı ailelerinin gelir durumunu "orta halli" olarak değerlendirse de bu kavram sorunlu yapısı ile ekonomik düzeyi betimlemede yetersiz kalmaktadır. Bu noktada katılımcılar asgari ücret ile kıyaslamaya giderek kendilerini orta halli bulmaktadırlar. Günümüz Türkiye'sinde asgari ücrete göre daha iyi gelire sahip olan ailelerin çocuklarının gelecek beklentileri ve hayalleri de orta halli olmayı sürdürmektedir.

\section{Gelecek Beklentileri ve Hayaller}

Bu başlık altında öğrencilerin gelecekte nasıl bir yaşam düşledikleri, okudukları bölüm ile ilişkili olarak nasıl bir kariyer planladıkları, mezun olduktan sonra nasıl bir işte çalışmak istedikleri ve ne gibi hayallerinin olduğunun öğrenilmesi amaçlanmıştır. Katılımcıların yanıtları "meslek seçimi" başlığında olduğu gibi bir tipleştirmeyi de olanaklı kılmaktadır.

Birincisi, ekonomik bağımsızlığa erişme, ev sahibi olma ve iyi bir aile kurma isteğinin öne çıktığı, beslenme, barınma ve üremeye dayalı temel gereksinimlerin doyumu üzerine kurulan hayaller. İkincisi ise mesleki başarı ile saygınlık kazanımına dayalı yaratıcı üretim ve kendini gerçekleştirme hayali. Bu noktada "kendini gerçekleştirme" hayali yalnızca ilkeli (özgeci) tercihte bulunanlara özgü olmamakta, plansız ya da edilgen tercih yapanlarda da okudukları bölümde "kendilerini yüksekte görmeği" (K6, 20, K) hedefledikleri gözlendiği gibi, yalnızca temel gereksinimleri doyumunun yeterli olacağını belirten ilkeli tercih yapan katılımcıların (K1, 19, K) da gözlendiği belirtilmelidir.

"Kadro açılmasını, üniversitede kalıp ders vermeyi istiyorum. Yüksek bir maaşa da gerek yok. 80'imde de olsam eğitim alıp serbest atlayıs yapmak istiyorum. Interrail tren ile Avrupa Turu ve Prag Kütüphanesi'ni görmek, tarihçilerle tartışmak isterdim." (K12, 28, E). 
“Ortadoğu'da çalışmak istiyorum. Kadın sorunlarn ile ilgi araştırmalar yapmak... Farklı ülkeleri gezmek, özellikle Hollanda'yı görmek, farklı hobiler geliştirmek, akordeon çalmayı öğrenmek gibi..." (K18, 21, K).

"Aşırı büyük bir beklentim yok, 13 yaşında bir kardeşim var haliyle [aileyi] kaybetme korkusu oluşuyor. Yani maddi kaygılarım olmamalı. Akademisyen olarak istediğim araştırmayı yaparak para kazanmak isterim. Şu an da projeden para kazanıyor olsaydım elbet daha iyi olurda ama tekno-markette yarı zamanl olarak çalışıyorum. Huzurlu ve mutlu bir ailem, seçtiğim arkadaşlarımın yanımda olduğu bir hayat isterim." (K20, 26, K).

"Hayatım düzenli olsun istiyorum, gelirim, tatil yapacağım günlerim belirli olsun. Yani [gelecek] belirsiz olmasın. Ama yarınımızı bilmiyoruz. Bu yüzden de geleceği gelmeden düşünmemeye çalışıyoruz. Ama yurtdışında eğitime devam etmek isterim tabi. Babamın Rent a Car işi var yazlarım o işle geçiyor ve ben bu işi yapmak istemiyorum. Uzun yol kaptanlı̆̆ı güzel olurdu." (K31, 29, E). Her ne kadar katılımcı yurtdışı eğitim hayali kuruyor olsa da uzun yol kaptanlığı yapmak istediğini belirtmekte, bu anlamda hayalinde okuduğu bölümde çalışmamanın yer almadığı söylenebilir. Benzer bir örnek istemediği Çocuk Gelişimi bölümünü tamamladıktan sonra istediği İngilizce Bölümü yerine Almanca "geldiğini" belirten, aynı zamanda bir müzik grubunda gitar çaldığını belirten katılımcıda da görülmektedir: "Gelecekte bir çocuk yuvası açıp orada dil eğitimi vermek istiyorum. Çocuk gelişimini isteyerek okumadım ama bunu kullanabilirim... Hayalimde ise yurtdışında müzik icra etmek var." (K35, 21, K).

Öne çıkan kavramlar arasında "belirlilik”, "risksizlik”, “huzur”, "mutluluk" vb. bulunması aynı zamanda öğrencilerin Türkiye'nin geleceğini "belirsiz" olarak nitelendirmeleri ile de ilişkilendirilebilir. Ancak katılımcılar her şeye rağmen karamsarlı̆̆ın ve umutsuzluğun çözüm getirmeyeceğini belirtmişlerdir: "Pek bir beklentim yok, iş olanakları açısından. Karamsar değilim, umut ederek devam ediyorum [yaşama]. Araştırma [yapmak] istiyorum, olanak verilmiyor. İki kişi ile olmaz ki, bir kişinin dediği ile hiç olmaz. Çallşırken gezmek, farklı kültürleri görmek isterdim." (K22, 22, E).

Mezun olduktan sonra iş bulmanın bölüm dolayısıyla zorluğu ve geleceğin de belirsiz oluşu kurulan hayallerde riskten uzak bir ölçüde monoton denebilecek çalışma ve izin günlerinin belirgin olduğu güvenceli -es- 
neklikten uzak- bir yaşamı öne çıarmaktadır. Ancak benzer hayaller gelecek kaygısının görece daha az olduğu bölüm öğrencilerinde de görülmektedir:

"Ekonomik bağımsızliğım olsun, çalıştığım işten memnun olayım, mutlu ve huzurlu, belirli risksiz bir hayatım olsun. Ailem ve çocuklarımla ormanla iç içe bir evim olsun." (K1, 19, K).

"İyi bir yurttaş olmak. Kariyer öncelikli düşünmek zorundayım, küçük kardeşim var ekonomik bağımsızlığımı kazanmam gerek. Başarılı bir akademik kariyer, düzenli bir yaşam bahçeli kamelyası olan bir ev. Fransa'yl, özellikle Paris'i motorla gezmek, tango öğrenmek..." (K7, 21, K).

"Gelecekten beklentim, huzurevinde hizmet vermek, mesleğimde saygr görmek, yaşlllarla iletişimde olmaya devam etmek. Gönül ister ki kendi yerimi açayım. Güveneceğim ve mutlu olduğum bir ailem ve arkadaşlarım olsun, doğa ile iç içe Akseki'deki gibi bir evim olsun isterim." (K8, 21, E).

"Gönüllü staj yapmak istiyorum, adliyede ya da hastanede. Mutlu olabileceğim bir işim olmall, kendimi yüksekte görmek isterim. Bu akademisyenlik olabilir. Lisede garsonluk yaptım, çalışmayı ve para kazanmayı seviyorum, güzeldi. Aslında tıp ya da gıda mühendisliğini istiyordum. Yabancı uyruklu olduğum için zorlanmadim, sinavda." (K6, 20, K).

"Gelecekten umutluyum, psikolog olacağım. İnsanları toplum hayatında gözlemlemeyi seviyorum. KPSS ile atanabileceğimi mesleğimi Doğu'da yaparak insanlara psikolog olarak faydalı olabileceğimi düşünüyorum." (K5, 19, K).

"Toplumun çocuklar konusunda bilinçlendirilmesini istediğimden sosyal sorumluluk projelerinde çalışmayı düşünüyorum. Doğu ve Güneydoğu'yu merak ediyorum ve oraya atanmak istiyorum Öncelikle topluma faydah olmak isterim. Hayalimde ise farklı kültürlere sahip, Afrika gibi, yaşam koşullarında, çalışmak var. O insanlara bazı şeyleri değiştirebilmelerinin kendi ellerinde olduğunu göstermek istiyorum." (K4, 25, K).

Psikoloji bölümü ve geleceğin mesleği olduğu düşünülen Gerontoloji bölümü öğrencilerinin, diğer bütün bölümlere kıyasla gelecek kaygılarının görece az olduğu gözlenmiştir. Felsefe, Arkeoloji, Sanat Tarihi, Eski Çağ Dilleri ve Kültürleri gibi bölümlerin öğrencilerinin iş bulma ve çalışma konusundaki kaygıları yüksekliğini korumaktadır. Dolayısıyla bu bölüm öğrencilerinde isteyerek/istemeyerek mezuniyet sonrası işsizliğe geçici bir çözüm olarak lisansüstü eğitim öne çıkmaktadır: 
“Çalışma olanakları kısıtll. Mesleğimi [Arkeoloji] anlatırken bile zorlanıyorum. Sen mezar kazıcısısin diyorlar. Bu şartlarda Akademik kariyer en iyisi... Bir at çiftliğim olsa, orada hayvanlarla iç içe yaşasam ne güzel olurdu." (K21, 22, K).

"Beklentilerim büyük değil, atanma da zor. Akademiden başka şans yok. Bir de şehirden uzak başımı sokacak bir evim olsun yeterli." (K27, 22, E).

Bu örneklerde "başka çıkar yol olmadığı için akademisyenlik mücadelesi" öne çıkarken, bazı katılımcılarsa akademisyenliği bir ideal olarak seçtiklerini belirtmişlerdir:

"Ĕ̆er mesleği iyi yapmak, akademisyen olmak istiyorsam aidiyeti değiştirmeli ve yurtdışına eğitime gitmem gerekli. Bunun için doktora yurtdışı programların araştırıyorum. İngiltere'de eğitim almak zor tabi ama Liverpool'da yaşamak isterdim. Evlenip, çocuk sahibi olmak, yalnız ölmemek. Kudüs'ü ve İskandinav ülkelerini gezmek..." (K11, 27, E).

"Yardımo doçent olmak, çevirilerimi [Latince Devlet İdaresinin Ahlaki Kurallar1] bitirip kitaplaştırmak istiyorum, politikacılara faydalı olur genel-geçer örnekler var geçmişten. Kendime kadar bir ekonomik birikim yeterli olur. İnsanlara çok bulaşmadan hoca olmak istiyorum. Ailemin kökeni Yunanistan'a dayanıyor, onların nereden geldiklerini öğrenmek istiyorum. En azından hayallerimden birini gerçekleştireceğim, haziranda Atina'ya gideceğim." (K13, 27, K).

Akademisyenliği seçeneksizlikten ya da iş olanaklarının olmayışı dolayısıyla isteyen öğrencilerin aksine, bir ideal olarak gören katılımcıların hayallerinin de daha çok okudukları bölüm ile ilişkilendirilmeye uygun olacağı düşünülmesine rağmen yine de farklılıklar da mevcuttur: “Gelecek için para değil, mutlu olmak istiyorum. Özel sektörde çalıştım ve mutlu değildim, yüksek lisans için döndüm. Gelecekte, North Carolina'da doktora yapmak, akademisyen olmak istiyorum. Güney Afrika'da toplumsal simflar ve suç oranlarn üzerine çalışmak isterim... Ütopik bir hayal olarak da Avustralya'da teknolojiden uzak, doğal bir yaşam sürmek..." (K20, 26, K). Bu noktada katılımc1 teknolojiden uzak bir ütopya hayaline sahip olsa da, aynı zamanda etkin bir şekilde interneti kullandığını da belirtmiştir. Bu bağlamda katılımcıların boş zaman etkinliklerine sonraki başlıkta değinilecektir. 


\section{Boş Zaman Etkinlikleri, İkili İlişkiler ve Geçmişe Özlem}

Araştırmada amaçlanan bir diğer konu da Edebiyat Fakültesi öğrencilerinin boş zaman etkinliklerinin, bu etkinliklerin önemli bölümünü oluşturduğu düşünülen ikili ilişkilerinin, evlilik ve birlikte yaşam pratiğine bakışlarının belirlenmesidir. Ayrıca katılımcıların geçmişe dair herhangi bir özlemlerine, Türkiye'nin bugünü ve geleceğine ilişkin görüşlerine de yer verilmiştir. Bu yanıtları tamamlayıcı olduğu düşünülen hangi tarihte yaşamak istedikleri de araştırılmıştır. Bunun nedeni olarak da genel yaşam memnuniyetlerinin yorumlanmasına katkı sağlayacağı düşünülmüştür. Çünkü birçok katılımcı genel yaşam memnuniyeti konusunda "memnunum" ile "yine de memnunum" arasinda gidip gelen yanitlar vermelerine rağmen, imkanları olsa başka bir ülkede başka bir hayat düşlediklerini dile getirmişlerdir. Bu durum da memnuniyetlerinin aslında "görece memnun" olarak değerlendirilmesini olanaklı kılmaktadır.

"Bisiklet sürmek, yolda olmak, televizyon, internet dizileri ve haber takibi yapıyorum. T24 ve Radikal gibi gazeteleri takip ediyorum Genel yaşam memnuniyetim fena değil, Antalya'da olmak memnuniyet verici ama her zaman daha iyisi olabilir... 7 yıldır görüştüğüm ve ciddi düşündüğü̈m bir arkadaşım var. Ĕ̆itim, kız arkadaşım ve filmin sonuna dair merakım hayata bağlıyor beni. Hayat kurma isteğimiz geleneksel değil, ama aileler öyle. Evlilik derdimiz yok ama şartlar belli. Aileler karşılıklı nişan istiyor. Partnerimden değil ancak ailelerden baskı oluyor. Bana sorarsan birlikte yaşam olmal, evliliğe hazırlar ve işin rengini gösterir. "Acaba birlikte yaşayabilecek miyiz?" sorusunun cevabını almış oluruz. Lisansta arkadaşlarla eve çıktık, dost-düşman belli oldu. Dışarıda zaman geçirir bazı şeyleri paylaşırsın ama birlikte yaşamak farklı bir tecrübe. Biraz "ekonomi" ile ilgili. [Bu noktada katılımcı, kökeni Yunanca oikonomia (oikia + nomos) sözcügüne dayanan ev idaresine gönderme yaptığını belirtmiştir.] Evlilik, toplumdaki bir anlaşma, cinsel özgürlüğ̈̈ ifade ediyor. Ancak boşanma kadının statüsünü kaybettiriyor, ataerkil düzende. Toplum kadına 2. el araba muamelesi yapıyor. Toplumda boşanma doğru görülmüyor. Kadın şiddete maruz kalsa bile baba evine dönmemek için bazı şeyleri sineye çekiyor. Çiftlerin imkanları olsa evlenmeden önce seyahate çıksalar, birlikte zaman geçirseler, kendilerini tanıma firsatı bulurlar. Ancak toplum bunu kaldıramıyor. Türkiye'nin geleceği karanlık... Atina'da 5. yüzyılda zengin bir vatandaş olmak, büyük düşünürlerle tanışak iyi olurdu..." (K12, 28, E). 
"Dizi, dans, roman, sosyal medya, Facebook, Instagram, internetten her gün haber. Dizi olarak internetten yabancı diziler, haber olarak da internet gazetelerini Google Gazetelikten okuyorum. Bölüm kitapları haricinde çok satan kitaplardan okuma listem var, ona devam ediyorum... İkili ilişkiler, ataerkillik dolayısı ile zorlaşıyor gün geçtikçe. Önceki arkadaşımdan da bu yüzden ayrıldım. Huzurlu olacağım kişilerle birlikte olmak istiyorum, neşeli kalabalık sıktı... Hayatımdan memnunum yine de, Türkiye'nin durumundan değil. Devlette torpilin dönmesi, yurtdışında kıymet verilirken mesleğe [Sosyoloji], burada değer görmemesi, ekonomik olarak gerileme... Cumhuriyet'in kuruluş mücadelesini canlı görmek isterdim. Tirmalayarak, kazıyarak, bütün zorluklara rağmen kurulan Cumhuriyet, bir başarı öyküsü. Kırılma anların yaşamak o dönemde gazeteci-yazarlık yapmak isterdim..." (K20, 26, K).

Elbette katılımcıların hayat tecrübelerinin yeterli olmadığı düşünülebilir, nostalji hissine nasıl kapıldıkları merak konusu olabilir. Ancak basitçe bir özlemden çok, yaşam standartlarının eskiye oranla düşüş göstermesi ile katılımclar "geçmişi arar" hale gelmişlerdir.

Okul harici zamanım AVM'de geçiyor çünkü bir giyim mağazasında satış danışmanı olarak çalışıyorum. Monoton ama her hafta sinemaya gidiyorum, aynı AVM'de. Tabi bölüm ile ilgili [Sanat Tarihi] kitap okuyor, bazen de müzeye gidiyorum. Erkek arkadaşım yok. Birlikte yaşam bir düzene bağhl olduğu sürece olumlu olabilir, tanıma ve hazırlık açısından [evliliğe]. İş hayatı ve okul kaygısı var. Mutsuzum, iş ve müşterilerin davranışları ve bizleri eziyor olmaları. Yalnızlık kaygısl, kimsesiz kalma korkusu da var. Türkiye [gelecek konusunda] bence bir yere gitmiyor, karamsarm bu konuda. Antalya bir antik kent olmasina rağmen özellikle turizm için bir kaç senedir daha yoğun gelen Iranlı turistleri AVM'ye yönlendiriyoruz. Örneğin Olbia Antik kentini gezdirmiyoruz da shopping fest'e götürüyoruz... Selçuklu Dönemi'nde yaşamak isterdim." (K9, 25, K).

Sanat Tarihi bölümde okuyan katılımcının dikkatini yine bölümün getirmiş olduğu bakış açısına bağlı sorunlar çekmektedir. AVM'de çalışmasının katkısını yadsımamak ile birlikte, Antik kentin, bölgenin turizminde öne çıkarılması gerektiği düşüncesi ve Selçuklu dönemini merak ediyor oluşu bölümün kazandırmış olduğu hayat görüşü ile ilişkilendirilebilir. Aynı zamanda katılımcı Selçuklu Döneminde yaşama isteğinin nedeni olarak da, dönemin mimarisinin zevklerine uygun oluşunu öne sürmektedir. 
"Her gün yazll yerel gazeteden, internet ve sosyal medyadan haber takibi yapıyorum, serbest zamanlarımda [Gerontoloji bölümü öğrencisi özellikle boş zaman yerine serbest zamanı tercih ettiklerini belirtmektedir]. PazartesiÇarşamba 18.00 ve 21.00 arası Japonca dersim var. Salı günü spor etkinliğim oluyor, basketbol ya da masa tenisi oynuyorum. Kız arkadaşım olmadı, daha önce. Elbette güveneceğim, yanında rahat hissedebileceğim birini arıyorum. Birlikte yaşama kişiden kişiye değişir, yapmam ama katı değilim. Bence evliliğin yerini alamaz. Türkiye'de clientelism beni bitiriyor. Bütün işler buna dayanıyor. Hak yenmesin. Bir yere geleceksem kendi çabalarımla olmal, clientelism'e gerek kalmadan. Sabredeceğiz. Öldürmeyen güçlendirir. Aileme karşı sorumluluklarım ve arkadaşlarım hayata tutunmamı sağlıyor. Pes etmemeliyiz. Bu, birazda basketboldan geliyor. Pes edene kızıyorum. Kaç sayıda geride olsam bırakmam, ne de olsa maç daha bitmedi." (K8, 21, E).

“Ormanda yürüyüş yapıyorum 1 aydır, Tünektepe'de köyde. Sabah kahvaltı yaparken haberleri izlerim... Erkek arkadaşım var, ciddi görüşüyoruz. Her gün görüşürüz ama 3,5 yıldır evlilik konusunu konuşmadık. Ondan gelen bir baskı yok ama insanlar tanıyınca ona baskı kuruyorlar. 1 sene birlikte yaşadık, olumlu tarafi kavga ediyorsun birbirini daha iyi tanıyorsun olumsuzluk onun ailesinin bilmemesiydi. Evlenmeden görüşmeye tahammülleri yok. Mektupta kalmışlar. Sonra evleri ayırdık, bir mahalle var arada... Yaşamdan memnun sayılırım, nefes almaktan mutluyum. Ama Türkiye berbat bir durumda, iyiye gideceğini sanmyorum, kimse de bunu göremiyor. Benzin zamlanır kimsenin umuru olmaz. Karamsar, umutsuz olmak istemiyorum. Bizler birilerinin akılların açmalıyız. Başka türlü olmaz. Başka bir zamanda doğsam bu 3.yüzyıl Helenistik dönem [olurdu], Sparta'da eğitimci olmak isterdim. Çünkü kadınların devlet yönetiminde söz hakkı almak için mücadele etmeleri beni etkiliyor." (K13, 27, K).

"Günlük haber takibi, kitap, roman, aşk, polisiye türünde, müzik ve kendimi geliştirecek dönem dizilerini izliyorum. Erkek arkadaşım yok. Kendim için düşünmüyorum [birlikte yaşamı] ve alternatif olarak doğru bulmuyorum, dini sebeplerden dolayı fakat yapana saygılıyım. Aile özlemine bağh sinir-stres, onun dışında memnuniyetsizlik yok. Hayata hep olumlu bakarım, sorunlarla savaşmayl severim. 60'lı ve 70'li yillarda öğrenci veya avukat olmak isterdim, siyasi olaylar ve Türkiye'nin durumu dolayısıyla. Mücadeleci ruh çok hoşuma gidiyor, öğrenciler sayıca az fakat mücadele ve başkaldırı var. Devletçe uygulanan siyaset yanlıştl, bu dönemde olduğu gibi. Bu döneme bakarsan kalabahı̆ız [öğrenci olarak] 
ama girişken değiliz, pasifiz.... Osmanlı'da yaşamak isterdim, eşitlik vardı padişaha rağmen. Gelenek ve göreneklere bağlılık insanlar arası ilişkiler daha samimi ve iyiydi. Çıkarcılık daha azdı." (K5, 19, K). Katılımcının eşitlik mücadelesi verme isteği onun aynı zamanda eşitlik olduğunu düşündüğü Osmanlı döneminde yaşama hayaline yönlendirdiği kendi yaklaşımını tutarlı kılmak adına yapılabilecek bir yorumlama olabilir. Ancak otorite ile mücadele konusunda otoriteryan bir kişilik sergilediği de düşünülebilir. Türkiye' nin geleceğine ilişkin kaygılarına yönelik olarak katılımcılar arasında görülen Osmanlı dönemine özlemin bulunuşunun ve "sistemin bozukluğunun" (K22, 22, E) alternatifi olarak da eski düzenin görülmesi şaşırtıcıdır.

"Edebiyat ile ilgilenirim, haber takibi sürekli... Nişanlılık var, evlilik şartlar olgunlaşınca. Birlikte yaşamayı olumlu bulmuyorum... Aile, beş kardeşim hayata bağlıyor. Aile kavramı ă̆ır bizde... Genel olarak hayattan memnunum ama Türkiye'nin geleceğinde bir şey yok. Kanunun işlenişi sıkıntı, sistem bozuk. Düşünmeye fırsat verilmiyor. Üzerimize baskı kuruluyor. Umutlar boşa çıkıyor... Osmanl Dönemi'nde Lale Devrinde Sarayda yaşamak isterdim." (K22, 22, E).

Buraya kadar bu başlık altında görüşlerine yer verilen katılımcılar boş zamanlarında okudukları kitapların daha çoğu bölüm ile ilgili ders kitapları olduğunu belirtmişlerdir. Bölüm dışından okudukları kitapların ayrıntılandırılması istendiğinde "aslında şu sıralar çok vakit bulamıyorum"un (K15, 19, K), "roman ve şiir"in (K19, $21 \mathrm{~K})$ yanında "Simon de Beauvoir" (K7, 22, K) "Ahmet Ümit ve Sabahattin Ali" (K17, 21, K) şeklinde yanıtlar da alınmıştır. Benzer bir durum katılımcıların Türkiye'nin geleceğine ilişkin görüşleri alınmak istendiğinde de yaşanmıştır: Katılımcılar "Karanlık" (K33, 29, E), "İyiye gidiyor" (K26, 23, K) ve "Siyasetle aram yok, kendimi düşünüyorum" (K25, 22, K) şeklinde çeşitlilik arz eden yanıtlar vermişlerdir.

"Inanmak istiyorum, umutlu olmasam da, gittikçe ayrumculık ve bireyselleşme arttı ve toplumsal değerler zarar görüyor. Insan ilişkilerinde siyasi düşüncelerin etkili olduğunu görüyorum ve artan imkanlara rağmen çocuk eğitiminin kötüleştiğini düşünsem de inanmak istiyorum her şeyin iyi olacă̆ına." (K4, 25, $\mathrm{K})$.

Aynı katılımcı okuduğu romanlar ve diğer konularda da ayrıntılı yanitlar vermektedir: "İskender Pala ve Nurdan Damla'nın Cemalnur Sargut'un eserlerini okurum. Dergi olarak Kafa, Bilim ve Teknik okuyorum. Erkek arkadaşım yok şu an. Ciddi bir ilişkim olmuştu, evlilik baskısı olmuştu, 'neden okuyorsun' şeklinde sorularda. Bunları aşmıştım, fakat özel sebeplerden dolayı ilişki 
bitti. Bu baskllara kulak asmayarak aştım ve kendi istediğimi yaptım. [Birlikte yaşam pratiğini] kendim için düşünmesem de bu meselenin karşılıklı dürüstlükle ilgili olduğunu düşünüyorum. Dürüstlük evliliğe hazırlık için önemli. Özel olarak yaşamdan memnunum ama toplum hayatından değil, siyasilerin insanları çok fazla ayrıştırdığını düşünüyorum. 10 yıl önce daha iyiydi insanların birbirine anlayış göstermesi açısından. Konferanslarda karşıt gruplar daha rahat tartışabilirdi. İlkokul yıllarımda her şey daha samimi ve gerçekti, ilişkiler vs. bakımından." (K4, 25, K).

Öğrencilerin boş zamanlarında öne çıkan bir etkinlik olan müzik bazı katılımcıları "hayata bağlamaktadır" (K11, 27, E), (K35, 21, K). "[Boş zamanımda] mizıka çalarım, masa tenisi oynamayı seviyorum, sosyal medyadan, Yeniçă̆ ve Diken'den haber takibi yapıyorum. Kız arkadaşım var, şartlar olgunlaşınca evlilik olur. Daha önce partnerden gelen bir baskı vardı. Toplum içinde Yakut çarşısında tokat attı ve gözlüğ̈̈m düştü. Bu bana bir tecrübe oldu, arkadaş seçimi konusunda. Birlikte yaşam konusunda partner toplum baskısına takıyor. Anne-babadan birlikte yaşadığımı saklanıyor. Bu sıkıntı oluyor 'insanlar ne der' diye. Evlilik iki insanın birlikte yaşaması bence zaten. Imza işin heyecanı... Mutluyum, müzik ve sevgi hayata bağhlyor, hayal kurarken gerçekçi olursan hayal kırıklı̆̆ı az olur. Liverpool'da 1960'larda yaşamak isterdim, '40-'43 doğumlu olmak, yani hippi çiçek çocuklar. Bunun sorumlusu da büyük ölçüde babamın beni Beatles ile büyütmesi..." (K11, 27, E).

Katılımcıların yaşama bakışlarını, geçmişte doğmuş olma isteklerini onların anne-babaları ile kurdukları ilişkiler ile bağlantılı düşünmek olanaklıdır. Ne de olsa Beatles ile büyüyen bir nesil, çocuklarına da aynı yaklaşımı vererek onların da benzer bir kültüre sahip olmasında etkili olmuştur. Çalışmanın sonraki başlığı da kuşakların birbirleri ile ilişkileri üzerinedir.

\section{Kuşaklararası İlişkiler}

Araştırmada katılımcıların önceki kuşak ile olan diyaloguna, hangi konularda birbirlerinden farklılaştıklarına, aynı zamanda kendilerine gelen eleştirilerin yanı sıra katılımcıların eleştirilerine de yer verilmiştir. Hangi konularda farklı kuşaktan bireylerin birbirlerini anlamakta zorlandıkları herhangi bir şekilde kuşak çatışması yaşayıp yaşamadıkları da aktarılmaya çalışılmıştır. 
"Birbirimizi şimdi anlamaya başladık, aslında ikiye ayırırım, üniversite öncesi ve sonrası şeklinde. 17-18 yaşlarında klasik ergenlik sorunları 'eve erken gel, geç kalma yemeğe'. Üniversiteden sonra problemler azaldı. Özgürlük için bir anahtardı üniversite. Oraya girince daha iyi anladık birbirimizi, hatta kendileri teşvik etti sosyalleşme konusunda. Karşılıklı bakış açısı değişti. Yaş ilerleyince iletişim daha yapıcı olunca aile içindeki sorunlarda azaldı... İki sebepten kuşak çatışması oluyor genel anlamda: Bir, büyüklerin yetiştiği ortam ile bizi yetiştirdikleri ortam farkl. İkincisi, iletişimsizlik. Birbirimizi farklı algllıyoruz... En çok sosyal medya ve telefon kullanımı eleştiriliyor. Bir bakıma haklılar tabi, ama önceki kuşak çağa uyum sağlayamıyor. Mecbur kaldıkları için kabul ettiler örneğin WhatsApp'ı, kendi çeorelerinin baskısından dolayı. Annem arkadaş çeoresinden dolayı kullanıyor. Kız arkadaşım yeni kullanmaya başladı, şimdi benden fazla kullanıyor, demek istediğim eleştirirken, kullanmaya başlayınca çokta farklı bir noktaya gelmiyorlar. Örneğin babamda oyun oynuyor, bilgisayarda... Bizim kuşakta marka takıntısı, bir mekanda var olabilmek, bir arkadaş çeoresinde var olabilme çabası var. Bu eylemler bir statü yüceltir diye düşünüyorlar bilinçaltında, kardeşimden biliyorum. Sosyal medyada herkes mutlu fotoğraflarda hatta paylaşmaktan bile mutlu, 'burdayım' diye." (K12, 28,E)

"Çok mükemmeliyetçiler, hep bir kıyaslama. 'A ̆ğabeyin bunu yaptl, sen neden öyle yapmiyorsun' diye eleştiriliyorum." (K1, 19, K).

"Babam ne yaptığımı [Eski Çağ Dilleri ve Kültürleri] anlamadı, daha İngilizce biliyor musun diye sordu. Ne zaman kadro alacă̆ımı da soruyor, anlamadı elimde olmadığını. Annem anladı ama babama anlatamadık. Kuşak çatışması da aramıdaki eğitim farkından oluyor. Annem de ilkokul mezunu ama azimli okumaya ben de okumalıyım dedi. Açık fikirli olduğu için O'na danışırım, babama değil. Halam da 'sen de artık bir baltaya sap ol, çalış okuma bitsin. Ne zaman evleneceksin, niye evlenmiyorsun?' diye sorup duruyor. Kendilerini geliştiremiyorlar. Kitap okumuyorlar. Hatta yerel seçimlerde oy verdiğimiz gün neyi oyluyoruz diye sorarken, evlilik programlarınin adların hatırlıyorlar." (K13, 27, K).

Katılımcılar önceki kuşaktan bireylerin empati kurmakta zorlandıkları için çatışma yaşadıklarını, iletişim konusunda zorlandıklarını belirtmişlerdir:

“Anlamadıkları nokta kendilerini unutuyorlar, şimdi genç değiller ama öyleydiler. Ataerkil kafadalar baskı kuruyorlar. Bencil ve düşüncesiz olduğumu söyler- 
ler ama lisede okuldan eve gidip gelirken sürekli telefon ederlerdi, şimdi aramıyorlar. Babam tutarsızdır. Küçük şeyleri abartır, büyüklere kızmaz. Memnuniyetsiz, dışarıda bir şeylere kızar gelince eve yansır." (K2, 19, K).

"Net anlamıyorlar, dedemle görüşmek istemiyorum, odama gidip kitap okurum. Yetişkinler muhafazakar oluyor, kıramıyorsun bu da bizi olumsuz etkiliyor, çünkü seni düşündüklerini söyleseler de anlamıyorlar..." (K18, 21, K).

Katılımcllar, kendilerine gelen eleştirilerin bir ölçüde önceki kuşak için de geçerli olabildiğini vurgulamışlardır:

"Yetişkinler telefonu, sosyal medyayı kullanmama laf ediyorlardı. Şimdi benden çok kullanıyorlar. Birçoğumuzun ise bağımlı olduğu doğru. Bundan dolayı hayatı kaçırıyorlar. Her şeyi, her fotoğrafı paylaşıyorlar. Ben de çok fotoğraf çekerim, anıdır dursun bir yerde. Her gittiği yeri her aldı̆̆g hediyeyi paylaşıyor. Hediyeni başkası ile paylaşır mısın?..." (K20, 26, K).

"Babamın evlendiği yaştayım ama 'sen daha çocuksun' der. 70'lerde çocuk olmakla 2000'lerde çocuk olmak aynı şey değil farklı ortamlar. Biz okumaya devam ediyoruz ama çocuk da değiliz. Anlamamaları iletişim kuramamalarından. Biz de hata yapıyoruz. Dünyayı bilmeden, onu eleştiriyoruz. Onlarsa eleştirel olmamızı eleştiriyor." (K24, 22, E).

Katılımcıların farklı kuşaklardan bireylerle ilişkilerinde yakın çevrelerinden örnekler vermelerinin, kendi yaşamlarından deneyimlerle açıklamalarının yararlı olacağı düşünülmüştür. Bir ölçüde katılımcıların bu noktaya meyilli oldukları söylenebilir, ancak doğrudan "kuşak çatışması" konusunu fazla kişiselleştirdiklerini düşünmek de yanlış olacaktır. Araştırmada Edebiyat Fakültesi öğrencilerinin yaşamlarından bir kesit sunarak betimleyici bir çalışma amaçlandığı için kişisel deneyimlere önem verilmiştir.

Kişisel deneyimlerin, yaşam şartlarının farklılık göstermesi kuşak çatışmasının farklı yorumlanmasını beraberinde getirmektedir: "Kuşak çatışması yaşıyoruz, Doğu-Batı kültür çatışmasından kaynaklı. Onlar benim, ben onların kültürüne ayak uyduramıyorum. Doğu-Batı çok farklı dünyalar, onların etkisinde geri kalmışlık var. Kültürel giyim kuşam baskısı ağır... O döneme göre davranıyorlar, günümüze yetişemiyorlar. Bugünün kültürünü teknoloji ilerletti. Bizi de fazla geniş ve rahat yaptı. Bu da eleştirilmemize neden." (K22, 22, E).

Kuşak çatışmasını kültür üzerinden değerlendiren bir başka katılımcı da durumu ailesinin "koruyucu, tutucu ve dindar" oluşları ile ilişkilendirmektedir. "Facebook'ta erkek arkadaşımla konuşmama izin vermiyorlar. [İkili 
ilişki konusunda] baskı var. Erkek arkadaşımda biraz baskı kuruyor ama bertaraf ederim ben." (K35, 21, K).

Katılımcıların görüşleri doğrultusunda, kuşaklar arasındaki ilişkilerde öne çıkan sorunlar olarak empati kuramamaya bağlı iletişim zorlukları, maddi unsurların, teknolojinin ve bilginin sürekli değiştiği farklı bir dönemde büyümenin getirdiği kültürel farklılık vb. sayılabilir. Yaşanan iletişim sorunlarına rağmen, katılımcılar öz-eleştiri yaparak kuşaklar arasındaki etkileşime yapıcı katkılarda bulunmaktadırlar.

\section{Sonuç}

Sosyoloji kuruluşundan bu yana farklı dallara ayrılarak insana ilişkin her konuyu araştırmaya devam etmektedir. Farklı dallara ayrılarak ortaya çıkan "sosyolojilerin" modern zamanların üretim ilişkilerinde bir zorunluluk olarak öne sürülen uzmanlaşma ile ilişkisinin kurulması olanaklı olmakla birlikte, farklı konuların derinlemesine çalışılmasını sağladığı da düşünülebilir. Yine modern zamanlarda yaşamın ayrı bir dönemi olarak öne çıkan ve önceleri sıklıkla psikolojiye konu edilen gençlik kavramına sosyolojinin de ilgisi son yıllarda giderek artmıştır. Gençliğin bu bağlamda insan yaşamındaki bir yaş aralığı, risklere maruz kalabileceği bir dönem, yetişkinliğe geçişteki bir basamak veya kendine özgü karakteristiklere sahip bir dönem olarak farklı yaklaşımlarla ele alınmasına bu çalışmada kısaca yer verilmiştir.

Çalışmaya konu edilen Akdeniz Üniversitesi Edebiyat Fakültesi öğrencileri ile yapılan görüşmelerde bölüm tercihi ve meslek seçiminin nasıl yapıldığı buna bağlı olarak da gelecek beklentileri ve hayallerinin nasıl şekillendiği araştırılmıştır. Meslek seçimi konusunda ilkeli, plansız ve edilgen tercihler şeklinde adlandırılabilecek farklı eğilimler gözlenmiş, bazı örneklerde de bu eğilimlerin iç içe geçtiği görülmüştür. Aynı zamanda gelecekten beklenti ve kurulan hayaller noktasında da temel gereksinimlerin doyumuna ve kendini gerçekleştirmeye dayalı olmak üzere iki farklı eğilim gözlenmiştir.

Gençliğe dair oluşan ön yargılardan biri olan "ciddi olmama" durumu, meslek seçimi konusunda belirli örnekler için geçerlidir. Bölüm tercihinin, "meraktan", "arkadaşın ikna etmesi" vb. şekilde yapıldığında gelecek beklentilerinin, yaşam memnuniyetlerinin de olumlu seyretmeyeceği 
aşikârdır. Benzer bir durum bireyin yetenek ve isteklerini ikinci plana atan ailenin baskısı ile yapılan tercihler için de geçerlidir. Çocuklarının ciddi olmayışını eleştiren, bu yüzden yaşamlarına "çeki-düzen" vermeye çalışan aileler, aslında onların bağımsız kararlar alarak kendi ayakları üzerinde durmalarına, kendi değerlerini, sosyal ve kültürel normlarını kazanarak toplumsal değişimin ana failleri haline gelmelerine engel olmaktadırlar. Ailelerin koruyucu ve tutucu tutumları, çocukları ile iletişim konusunu zorlaştırmakta, onların risklere maruz kalabilme olasılığını arttırmaktadir.

Katılımcılar ile yapılan görüşmeler sonucunda seçilen bölümlere göre öğrencilerin yaşama bakışlarının değiştiği, farklı sorunlara odaklandıkları görülmüştür. Bu da yaşamlarının geri kalanını şekillendirecek olan lisans eğitiminin önemini bir kez daha vurgulamaktadır. Çünkü her bölüm, öğrencisine farklı bir paradigma kazandırmakta, yaşamın farklı bir yönüne eğilmelerini olanaklı kılmaktadır.

Yapılan meslek seçimleri kendi tercihleri dolayısıyla olmadığında, gençlerin gelecek beklentileri düşmekte, buna bağlı olarak yaşam memnuniyetleri etkilenmekte, hayalleri de farklı işleri icra etmek üzerine kurulmaktadır. Hatta her ne kadar kendi tercihleri ile bölüm seçimini gerçekleştirmiş olsalar bile, hayallerinde farklı mesleklerde çalışmanın söz konusu olduğu durumlar da gözlenmiştir.

Gençler hakkında öne çıkan bir başka ön yargı da onların risk almaya, özel sektörde çalışmaya daha istekli oldukları yönündedir. Oysaki yapılan görüşmelerde birçok katılımcının gelecekte belirsizlikten uzak, risksiz ve mümkünse devlette çalışmayı düşledikleri ortaya çıkmıştır. Bunun nedenleri arasında piyasa şartlarının güvenilmezliği, esnek üretim ilişkilerinin doğurduğu belirsizlik, özel sektörün yüksek ücretlere rağmen devlet sigortasını ve güvencesini sunamaması sayılabilir. Yaşamları boyunca sürekli değişen eğitim sistemine, farklılaşan sınav yapısına şahit olan, gelecek kaygısı ile yetişen gençlerin belirlilik arayışı da şaşırtıcı değildir. Bu noktada birçok katılımcının Türk kültüründe öne çıkan "nohut oda bakla sofa" "azıcık aşım ağrısız başım" gibi yaklaşımları benimsedikleri, parayı ikinci plana atarak huzurlu bir gelecek aradıkları gözlenmiştir. Ancak huzurlu bir gelecek için öne çıkan bölüm tercihinin öneminin lisans eğitiminin başlamadan önce farkına varıldığının söylenmesi ise güçtür. Meslek seçimi gibi büyük kararların, saatler içinde gerçekleştirilen sınav sonucu 
ile yapılması, gençlerin geleceğini adeta pamuk ipliğine bağlamaktadır. Ayrıca lise eğitimi boyunca öğrencilerin yeteneklerini keşfetmelerini sağlayacak rehberlik servislerinin de kısıtlı oluşu tercih konusunun "şans"a bırakılmasında etkili olmaktadır. Böylece öğrenciler, arkadaşlarının istekleri, ailelerinin dayatmaları ya da ani gerçekleşen bir olayın etkisi altına girerek tercih yapmaktadirlar.

Yapılan araştırmada kişisel yeteneklerini, okumak istedikleri bölümün nitelikleri ile değerlendiren öğrencilerin gelecek beklentilerinin, yaşam memnuniyetlerinin ve özgüvenlerinin yüksek olduğu gözlenmiştir. Elbette seçilen bölümün, örneğin psikolojinin, iş olanakları, bulunduğu fakültede yüksek statüde görülmesi, üniversite sınavından alınan yüksek puan ile girilmesi gibi kriterler dolayısıyla bu mesleğin eğitimini alan öğrenciler kendilerini ayrıcalıklı hissetmektedirler. Tercih konusu her ne kadar ciddiye alınsa da seçilen bölümlerin (Eski Çağ Dilleri ve Kültürleri, Felsefe gibi) iş olanaklarının kısıtlı oluşu, ailelerin bazı mesleklere fazla değer vermeyişi ve ekonomik olarak getirisinin olmayacağına dair olan inançları dolayısıyla öğrencilerin yaşam memnuniyetleri, gelecek beklentileri olumsuz etkilenmektedir.

Bunun sonucunda hem bir akademik kariyer ideali olarak hem de mezun olduktan sonra yaşanacak olası bir işsizlik durumunu önleme amacıyla lisansüstü eğitim programları öğrenciler için cazip hale gelmektedir. Uzayan eğitim süreleri dolayısıyla aileler ve toplum nezdinde bu bireyler ge(n)ç kalmaktadır. Bu durum gençliği yetişkinlik için bir basamak ve aşama olarak gören yaklaşımı hatırlatsa da aslında gençlik içinde hem yetişkinliğe hem de çocukluğa ait özellikler barındıran yaşamın farklı bir dönemini ifade eder. İçinde kaygıları, hataları, korkuları, riskleri olduğu kadar değişimleri, heyecanları da barındırdığ i için toplumun her kesiminin kontrol altına almak istediği sosyal bir grup olan gençlik, eğitim, aile ve sosyo-ekonomik değişkenler dolayısıyla her birey için farklı bir deneyimi işaret etmekte, homojenlikten uzak, oldukça kişisel bir süreç/dönem olarak insan yaşamındaki yerini almaktadır. 


\section{KAYNAKÇA}

Becker, H. S. (2014). Mesleğin incelikleri: sosyal bilimlerde araştırma nasıl yürütülür? (L. Ünsaldı, B. Öztürk, H. E. Mescioğlu, Ş. Geniş, G. Metin, Çev.). Ankara: Heretik Yayıncilık.

Berg, B. L. ve Lune, H. (2015). Sosyal bilimlerde nitel araştırma yöntemleri. (H. Aydın Çev. Ed.). Konya: Eğitim Yayınevi.

Bendit, R. (2006). Youth sociology and comparative analysis in the european union member states. Revista de Sociologia: Papers 79, 49-76.

Bourdieu, P. (2016). Sosyoloji meseleleri. (F. Öztürk, B. Uçar, M. Gültekin, A. Sümer, Çev.). Ankara, Heretik Yayıncılık. (1981).

Fırat, D. (2013). Bit(iril)meyen gençlik. D. Lüküslü ve H. Yücel (Der.). Gençlik halleri: 2000'li yıllar Türkiye'sinde genç olmak, Ankara: Efil Yayınevi.

Lüküslü, D. (2015). Türkiye'de "gençlik miti": 1980 sonrası Türkiye gençliği. İstanbul: İletişim Yayınları.

Lüküslü, D. ve Yücel, H. (2013). 2000'li yılları gençlik üzerinden okumak. D. Lüküslü ve H. Yücel (Der.) Gençlik halleri: 2000'li yıllar Türkiye'sinde genç olmak, Ankara: Efil Yayınevi.

O'Connor, A. (2004). The sociology of youth subcultures. Peace Review 16(4), 409-414.

O'Reilly, J., Eichhorst, W., Gábos, A., Hadjivassiliou, K., Lain, D., Leschke, J., ... Villa, P. (2015). Five characteristics of youth unemployment in Europe: flexibility, education, migration, family legacies, and EU policy. Sage Open January-March 2015, 1-19. 18 Ekim 2016 tarihinde $\quad$ http://journals.sagepub.com/doi/pdf/ 10.1177/215824 $\underline{4015574962}$ adresinden erişildi.

Sennett, R. (2011). Karakter aşınması, (B. Yıldırım, Çev.). İstanbul: Ayrıntı Yayınları.

Temiz, H. E. (2004). Eğreti istihdam: işgücü piyasasında güvencesizliğin ve istikrarsızlığın yeni yapılanması. Çalışma ve Toplum Sayı: 2, 5580.19 Aralık 2016 tarihinde http://www.calismatoplum.org/sayi2/makale3.pdf adresinden erişildi.

Wyn, J. (2011). The sociology of youth: a reflection on its contribution to the field and future directions. Youth Studies Australia 30(3), 34-39. 
Ekler

\section{Ek 1- Katılımcıların Listesi}

Katılımcı 1 (K1, 19, K): Psikoloji Bölümü (ilk tercih, isteyerek) 1. Sınıf öğrencisi. 19 yaşında. Kadın. Bolu doğumlu. İki kardeş. Anne ev hanımı, baba emekli.

Katılımcı 2 (K2, 19, K): Psikoloji Bölümü (ilk tercih, isteyerek) 1. Sınıf öğrencisi. 19 yaşında. Kadın. Antalya doğumlu. Tek kardeş. Anne memur, baba mali müşavir.

Katılımcı 3 (K3, 20, K): Psikoloji Bölümü (ilk tercih, isteyerek) 1. Sınıf öğrencisi. 20 yaşında. Kadın. Van doğumlu. İki kardeş. Anne ev hanımı, baba emekli.

Katılımcı 4 (K4, 25, K): Psikoloji Bölümü (ilk tercih, isteyerek) 1. Sınıf öğrencisi. 25 yaşında. Kadın. Antalya doğumlu. Üç Kardeş. Anne ev hanımı, baba şoför. 3 kardeş.

Katılımcı 5 (K5, 19, K): Psikoloji Bölümü (ilk tercih, isteyerek) 1. Sınıf öğrencisi. 19 yaşında. Kadın. Ağrı doğumlu. Dokuz kardeş. Anne ev hanımı, baba çiftçi.

Katılımcı 6 (K6, 20, K): Psikoloji Bölümü 1. Sınıf öğrencisi. 20 yaşında. Kadın Yabancı uyruklu.. İki kardeş. Baba esnaf.

Katılımcı 7 (K7, 22, K): Gerontoloji Bölümü (ilk tercih, isteyerek) 3. Sınıf öğrencisi. 22 yaşında. Kadın. Antalya doğumlu. İki Kardeş. Anne ve babanin esnaf lokantası var.

Katılımcı 8 (K8, 21, E): Gerontoloji Bölümü (ilk tercih, isteyerek) 2. Sınıf öğrencisi. 21 yaşında. Erkek. Antalya doğumlu. İki kardeş. Anne ev hanım1, baba temizlik personeli.

Katılımcı 9 (K9, 25, K): Sanat Tarihi Bölümü 4. Sınıf öğrencisi. 25 yaşında. Kadın. Balıkesir doğumlu. İki kardeş. Anne ev hanımı, baba çiftçi.

Katılımcı 10 (K10, 22, E): Sanat Tarihi Bölümü (ilk tercih, isteyerek) 4. Sınıf öğrencisi. 22 yaşında. Erkek. Sivas doğumlu. İki kardeş. Anne ev hanımı, baba emekli memur.

Katılımcı 11 (K11, 27, E): Sanat Tarihi Bölümü (ilk tercih, isteyerek) Yüksek Lisans 1. Sınıf (2. Dönem) öğrencisi. Arkeoloji Bölümü Lisans Mezunu 27 yaşında. Erkek. Gaziantep doğumlu. Tek kardeş. Anne ve baba emekli biyolog. 
Katılımcı 12 (K12, 28, E): Eskiçağ Dilleri ve Kültürleri Bölümü (ilk tercih, isteyerek) Doktora 1. Sınıf (2. Dönem) öğrencisi. 28 yaşında. Erkek. İzmir doğumlu. İki kardeş. Anne ev hanımı, baba emekli.

Katılımcı 13 (K13, 27, K): Eskiçağ Dilleri ve Kültürleri Bölümü (ilk tercih, isteyerek) Doktora 1. Sınıf (2. Dönem) öğrencisi. 27 yaşında. Kadın. İzmir doğumlu. Tek kardeş. Anne emekli, baba hastanede personel.

Katılımcı 14 (K14, 19, K): Türk Dili ve Edebiyatı Bölümü 1. Sınıf öğrencisi. 19 yaşında. Kadın. Antalya doğumlu. İki kardeş. Anne ev hanımı, baba kuaför.

Katılımcı 15 (K15, 19, K): Türk Dili ve Edebiyatı Bölümü 1. Sınıf öğrencisi. 19 yaşında. Kadın. Ankara doğumlu. İki kardeş. Anne ev hanımı, baba emekli emniyet müdürü.

Katılımcı 16 (K16, 19, K): Türk Dili ve Edebiyatı Bölümü 1. Sınıf öğrencisi. 19 yaşında. Kadın. Bursa doğumlu. Tek kardeş. Anne ve baba tekstilci.

Katılımcı 17 (K17, 21, K): Sosyoloji Bölümü (ilk tercih, isteyerek) 3. Sınıf öğrencisi. 21 yaşında. Kadın. Eskişehir doğumlu. Tek kardeş. Anne ve baba devlet iş̧̧isi.

Katılımcı 18 (K18, 21, K): Sosyoloji Bölümü (ilk tercih, isteyerek) 3. Sınıf öğrencisi. 21 yaşında. Kadın. Malatya doğumlu. İki kardeş. Anne ev hanımı, baba emekli şoför.

Katılımcı 19 (K19, 21, K): Sosyoloji Bölümü (ilk tercih, isteyerek) 3. Sınıf öğrencisi. 21 yaşında. Kadın. Antalya doğumlu. Üç kardeş. Anne ev hanımı, baba devlet memuru.

Katılımcı 20 (K20, 26, K): Sosyoloji Bölümü Yüksek Lisans 1. Sınıf (2. Dönem) öğrencisi (Sosyoloji Lisans Mezunu). 26 yaşında. Kadın. Antalya doğumlu. İki kardeş. Anne ev hanımı, baba emekli.

Katılımcı 21 (K21, 22, K): Arkeoloji Bölümü (ilk tercih, isteyerek) 4. Sınıf öğrencisi. 22 yaşında. Kadın. Ankara doğumlu. İki kardeş. Anne ev hanim1, baba mobilyac1.

Katılımcı 22 (K22, 22, E): Felsefe Bölümü 3. Sınıf öğrencisi. 22 yaşında. Erkek. Hakkari doğumlu. Altı kardeş. Anne ve baba memur.

Katılımcı 23 (K23, 22, K): Felsefe Bölümü 4. Sınıf öğrencisi. 22 yaşında. Kadın. Hatay doğumlu. Tek kardeş. Anne ev hanımı, baba yurtdışında çalışıyor.

Katılımcı 24 (K24, 22, E): Felsefe Bölümü 1. Sınıf öğrencisi. 22 yaşında. Erkek. Antalya doğumlu. Tek kardeş. Anne ev hanımı, baba işçi. 
Katılımcı 25 (K25, 22, K): Felsefe Bölümü (ilk tercih, isteyerek) 4. Sınıf öğrencisi. 22 yaşında. Kadın. Adana doğumlu. Tek kardeş. Anne ev hanımı, baba emekli uzman çavuş.

Katılımcı 26 (K26, 23, K): Coğrafya Bölümü (ilk tercih, isteyerek) Yüksek Lisans 1. Sınıf (2. Dönem) öğrencisi. 23 yaşında. Kadın. Antalya doğumlu. Tek kardeş. Anne ev hanımı, baba esnaf.

Katılımcı 27 (K27, 22, E): Tarih Bölümü (ilk tercih, isteyerek) 2. Sınıf öğrencisi. 22 yaşında. Erkek. Antalya doğumlu. İki kardeş. Anne ev hanım1, baba nakliyeci.

Katılımcı 28 (K28, 22, E): Tarih Bölümü 2. Sınıf öğrencisi. 22 yaşında. Erkek. Antalya doğumlu. İki kardeş. Anne hemşire, baba muhasebeci.

Katılımcı 29 (K29, 22, E): Tarih Bölümü 2. Sınıf öğrencisi. (ilk tercih, isteyerek) 22 yaşında. Erkek. İzmir doğumlu. İki kardeş. Anne ve baba çiçekçi, firma sahibi

Katılımcı 30 (K30, 23, E): Tarih Bölümü 4. sınıf öğrencisi. 23 yaşında. Erkek. Antalya doğumlu. Tek kardeş. Anne ev hanımı, baba emekli.

Katılımcı 31 (K31, 27, E): İngiliz Dili ve Edebiyatı Bölümü 4. Sınıf öğrencisi. 27 yaşında. Erkek. Antalya doğumlu. Tek kardeş. Anne ev hanımı, baba araba kiralama firma sahibi.

Katılımcı 32 (K32, 22, K): İngiliz Dili ve Edebiyatı Bölümü 4. sınıf öğrencisi. 22 yaşında. Kadın. İki kardeş. Anne ve baba öğretmen.

Katılımcı 33 (K33, 29, E): Alman Dili ve Edebiyatı Bölümü 4. Sınıf öğrencisi. 29 yaşında. Erkek. Antalya doğumlu. Tek kardeş. Anne ve baba otel sahibi.

Katılımcı 34 (K34, 23, E): Alman Dili ve Edebiyatı Bölümü 1. Sınıf öğrencisi. 23 yaşında. Erkek. Yabancı uyruklu. Tek kardeş. Anne dükkan sahibi.

Katılımcı 35 (K35, 21, K): Alman Dili ve Edebiyatı Bölümü 1. Sınıf öğrencisi (Çocuk Gelişimi ve Eğitimi Önlisans mezunu). 21 yaşında. Kadın. İzmir doğumlu. İki kardeş. Anne ev hanımı, baba emekli. 


\section{Kaynakça Bilgisi / Citation Information}

Tezcan, F. (2018). Üniversite gençliğinin meslek seçimi ve gelecek beklentileri: Akdeniz üniversitesi edebiyat fakültesi örneği. OPUS Uluslararası Toplum Araştırmaları Dergisi, 8(Gençlik Araştırmaları Özel Say1s1), 27-57. 